\title{
THE NATURE OF RADICAL ISLAMIC GROUPS IN SOLO
}

\author{
Muhammad Wildan \\ UIN Sunan Kalijaga, Yogyakarta - Indonesia
}

\begin{abstract}
Radical Islamism is a challenging new phenomenon in the modern world, including Indonesia. Solo presents an especially interesting case because of the disproportionate nature of the radical Islamic groups that have emerged here especially that of the Front Pemuda Islam Surakarta (FPIS) as well as other vigilante groups in the city. This paper will explore and map out the nature of Islam in Solo and asks what triggers the the emergence of the radical groups here. Dramatic changes at the national level have made Solo more politically conducive for radical Islamic groups, but this is not the only reason why they have flourished. In addition, historical and sociological factors may help such groups to emerge. Hence, the dominance of the abangan group (the nominal Muslims) and the intensity of dakwah (preaching) conducted by some Islamic groups has given rise to the 'instant' Muslims who see Islam as the ultimate solution to their problems. The call for jihād and the application of shari' ah laws are among the contentious political style that the groups propagated. It is these issues that the paper is interested to investigate.
\end{abstract}

Keywords: Radical Islam, jihād, Ngruki, abangan.

\section{Introduction}

Bali blast on October 12, 2002 has put Pondok Ngruki in particular and Solo in general in a global spotlight. The involvement some of Pondok Ngruki's graduates and its networks in Solo in the bombings has drawn many people's attention to this specific area. Previously Solo is identical the royal Mataram kingdoms, the heartland of Javanese culture, graciousness and well-mannered ladies, and 
gorgeous batiks. ${ }^{1}$ Currently, to talk about the Solo city, we could not avoid to discuss the existence of Pondok Ngruki and its related radical Islamic movements such as Usrah (1980s), Jama'ah Islamiyah (JI, 1993), KOMPAK 2 of DDII (1998), Majelis Mujahidin Indonesia (MMI, 2000), and Jama'ah Ansharut Tauhid (JAT, 2008). In fact, the phenomenon of Islamic radicalism in Solo is also characterized by the existence of some vigilante groups such as Front Pemuda Islam Surakarta (FPIS), Laskar Hizbullah, and Laskar Jundullah. All above assure my assumption that Solo is a fertile land for religious radicalism. The existence of these radical Islamic groups is interesting to study especially to reveal the real problem behind these phenomena.

Radical Islamic groups are not arising from a single factor, but many different ones. Some factors intertwined each other which finally gave to the rise of such radical groups. However, while Indonesian Muslims generally undergo the same global and national phenomena, some local factors may also play a significant role in this occurrence. In the global context, the heightening of religious consciousness among Indonesian Muslims is due partly to the modernization and globalization processes. While in the national context, the political conduciveness plays a significant role in the rising of Islamic radical groups in many different parts of Indonesia. This paper will observe the phenomena of radical Islamic groups in Solo not only from the above perspectives, but also from some local characteristics of Solo. the distinct character of Solo culture such as ethnicity, economics, and religion are the central factors to the rise of Islamic radical groups. As far as the nature of Islam in Solo is concerned, I should pay attention to the domain of religion, especially to the Islamization process of the lower-class of the abangan, who being deprived socially, economically, and politically, tend to resort to Islam as their way out from their problem. It is this kind of 'instant' re-Islamization that finally led them to the fold of Islamic radicalism.

\section{The Framework of Radical Islamism}

In the perspective of social movement, the phenomenon of Islamic fundamentalism can be viewed as a symptom of social resistance, rather than to see Islam as the source of violence.

\footnotetext{
${ }^{1}$ Batik refers to a generic wax-resist dyeing technique used on textile.

${ }^{2}$ KOMPAK stands for Komite Aksi Penanggulangan Akibat Krisis (Action Committee for Crisis Response).
} 
According relative deprivation theory, a social movement could emerge due to social changes which influence the social structure of a society. Unwanted cultural changes forced some communities to shift the direction of the changes to meet their necessities. In the context of Solo, social and cultural changes are influenced by modernization and globalization, political conduciveness, and local cultures of Solo. Globalized-world as a result of modern technology has shrunk the world into a global village. The rapid mainstream of information and technology has marginalized the role of religion in the society, especially Muslims. In Islamic fundamentalism perspectives, modernization is viewed as an immense threat for Muslims since it is not only a concept but it is a social process which produces social products. Traditional Islamic values is marginalized, swept out, and even replaced by Western values. Conventional Islamic preaching no longer could restrain the mainstream of modernization from the West. Among the influence of modernization and globalization is the widely spread of secularism as a part of ghazw al-fikr (intellectual infiltration). The inabilities of some Muslims' groups to follow the beat of modernity have given the rise of such Islamic revivalist groups as a way to counter to modernization. The demand of shari'ah in many Muslim countries is one of the ways of Muslims to counter Westernmodernization. However, since the mainstream is led by Western countries, the encounter of modernization and globalization is also filled with the sentiment of anti-Western countries. The hegemonic power of some Western countries toward Muslim countries to some extend also heightened the situation. The emergence of Jama'ah Islamiyah (JI) in Ngruki may be taken as a case point.

On the political sphere, on the other hand, the dramatic political change in Indonesia is such a conducive atmosphere for the emergence of radical Islamic groups. Political pressure of the Old and New Order to some extend has deprived the society, especially Muslims from participating in the political life.. Unsurprisingly, therefore, the downfall of Suharto regime in 1998 was marked by the emergence of some radical Islamic groups as part of the halted Islamic revivalism since the early 1980s. Despite some disappointment among Muslims during the New Order era, Islamic religious life was blossoming especially in the last ten years. ${ }^{3}$ The Islamic resurgence was featured by

3 Azyumardi Azra, "Globalization of Indonesian Muslim Discourse: Contemporary Religio-Intellectual Connections between Indonesia and The Middle East," in Johan 
the increasing of religious sermons in urban areas, the establishment of some Islamic institutions, the more intensive usage of Muslims' formal dress, and finally the uprising phenomenon of the formalization of shariah Islam. ${ }^{4}$ Eventually, the ongoing process of "santrinization" 5 marked the beginning of Indonesian Muslim society era. The dramatic changes of the politics to the Reformation Era have escalated the Islamic resurgence in general. On the other hand, the political tension was followed by some ethnic conflicts in some regions, especially religious conflicts such as in Poso and Ambon. Not only was the current climate support the steadily religious resurgence from the New Order, ${ }^{6}$ but it also gave the rise of some radical Islamic groups.

Tantamount to that, the local social culture of Solo plays a significant role in the dissemination of the ideals of Islamic resurgence in the form of radicalism. The Solonese especially Muslims have a distinctive characteristic culture which is shaped by many factors such as ethnicity, economics, politics, and religion. The characteristics of society in the form of uniformities and regularities create such kind of system or structure in which the society lives together. ${ }^{7}$ Therefore, the above factors not only affected to the behaviour and social structure of the society, but also gave significant impact toward the distinct culture of the Solonese. In this respect, Brenkman asserts that "culture is a site of reciprocal relationships and mutual understandings" including social domination, exploitation, and power pervasive. ${ }^{8}$ Historical backgrounds of the Solonese since the early years of its formation

Meuleman, Islam in the Era of Globalization: Muslim attitude towards modernity and identity (London: Routledge-Curzon, 2002).

${ }^{4}$ Bahtiar Effendy, Islam and the Sate in Indonesia (Singapore: ISEAS, 2003).

5 "Santrinization" is from the term santri (boarding school pupils), but in general it to refer to devout Muslims. The term santrinisasi is an abundant shifting from abangan to devout Muslim.

${ }^{6}$ According to the survey conducted by the Centre for Islamic and Social Studies (Pusat Pengkajian Islam \& Masyarakat, PPIM) UIN Syarif Hidayatullab Jakarta, there are significant increasing percentage of Muslims who agree to the implementation of Islamic shari ${ }^{-}$ab from $58 \%$ in 2001 to $67 \%$ in 2002 . That it should be the government that reinforce the implementation of Islamic shariah from $61,4 \%$ in 2001 to $71 \%$ in 2002. Further on this account see "Makin Saleh, Makin Curiga," Tempo, December 30, 2001, pp.48-49; "Makin Agamis di Tahun Kemudian," Tempo, December 29, 2002, p. 87.

${ }^{7}$ E.E. Evans Pritchard, Social Anthropology (London: Cohen \& West Ltd, 1969), p. 23.

${ }^{8}$ John Brenkman, Culture and Domination (Ithaca: Cornell University Press, 1987), p. vii. 
resulted in the majority of abangan in Solo. History records that the lower level abangan Javanese has been undergoing such social, economics, and political deprivations. On the other hand, the failure of religious and cultural leaders to bond the society has fragmented them into such loose society. In turn, it was within such loose abangan society that any social revivalism is flourishing. Many religious leaders are successful in framing the current social, political, and global situation with Islamic issues and finally lead them into a certain social movement. It is such Islamic doctrines as shari $a b$ which they believe could solve their current problems fast and precisely. Such instant convert' from abangan to pious Muslims, finally, leads them to radical Islamism.

\section{Radical Islamic Groups in Solo}

Radical Islamism has become one of the phenomena of social radicalism in Solo. Apart from the current radical Islamism, history records that social radicalism in Solo ranges from "left" to "right" wings. Not only did radicalism flourish prior to the Indonesian independence, it also blossom after the Indonesian independence during both the Old and New Order political system. While such radicalism is not quite significant in other cities, many people believe that there should be some local culture which partially takes part in such radical activities. Therefore, the history of radicalism in Solo is significant to see this phenomena comprehensively, especially why such activities continuously happened during the current the Reformation Era.

Obviously, social radicalism should be distinguished from Islamic radicalism in Solo. Prior to the Indonesian independence, the development of the Sarekat Islam (1912) in Solo eventually had given rise to social radicalism. That is the reason why Shiraishi ${ }^{9}$ asserts that the social movements in Solo gave much influence to the emergence of social movements in other parts of Indonesia. In Solo itself, the SI became a vehicle for the grass-root to protest against the government at the time, the Dutch government as well as the kingdoms. In addition to the central role of the Solonese in the Javanese culture, John Pemberton and Stephen Headley focus their attention to

\footnotetext{
9 Takashi Siraishi, An Age in Motion: Popular Radicalism in Java 1912-1926 (Itacha, N.Y.: Cornell University Press, 1990).
} 
Surakarta as the heartland of the Javanese culture. ${ }^{10}$ To add another social radicalism in Solo, anti-Chinese riot broke up in this region in 1980 followed by the same riots in other regions in Central Java. The emergence of Mega-Bintang coined by Mudrick M. Sangidoe of Solo prior to the election of 1997 was also a radical phenomenon of the alliance between the enormous followers of the Partai Demokrasi Indonesia Perjuangan (Indonesian Democratic Party of Struge, PDI-P) and the tiny mass of Partai Persatuan Pembangunan (United Development Party, PPP). ${ }^{11}$ Finally, the social riots prior and after the downfall of Suharto regime were also significant phenomena to include to the radical characteristics of the Solonese. Although Solo was far from the central government of Indonesia, the riots in the city was as worse as those in Jakarta. Undeniably, therefore, several social observers state that Solo is a barometer of national stability.

Turning to the Islamic radicalism sphere during the New Order, Pondok Ngruki was the only phenomenon of Islamic radicalism in the region. The oppositions of Abdullah Sungkar and Abu Bakar Ba'asyir to the government in the late 1970s were in the form of their rejection to be involved in the election and also to the Pancasila. Their involvement in the Negara Islam Indonesia (NII) of Adjengan Masduki was finally followed the case of Komando Jihad in the region, i.e, the assassination of Purwanto, vice rector of the Universitas Sebelas Maret, UNS (1979), and also Lampung Berdarah (1989). ${ }^{12}$ The detention of Sungkar and Ba'asyir on the accusation of undermining the government in the early 1980s even did not stop them. After being released 1984, they were involved again in another Islamic movement

\footnotetext{
${ }^{10}$ John Pemberton, On the Subject of 'Java' (Ithaca \& London: Cornell University Press, 1994); Stephen C. Headly, Durga's Mosque: Cosmology, Conversion and Community in Central Javanese Islam (Singapore: ISEAS, 2004).

11 The slogan of Mega-Bintang was enormously responded by their constituents in many big cities such as Surabaya, Pasuruan, Madura, and Banjarmasin. Along with the eruption of this 'social movement', the PPP of Solo was engaged in putibisasi ('whitening') campaign to counteract of kuningisasi ('yellowing') of Golkar cadres who were painting the town to match the party colour. Further, see John T. Sidel, Riots, Pogroms, Jibad: Religious Violence in Indonesia (Ithaca and London: Cornell University Press, 2006), p. 64.

12 Known also as Talangsari incident or the Terror of Warsidi. Further see Abdul Syukur, Gerakan Usrah di Indonesia: Peristiwa Lampung 1989 (Yogyakarta: Penerbit Ombak, 2003).
} 
known as Usrah, ${ }^{13}$ a movement to recruit more members of the NII. Finally, the harsh political attitude of the government to them and Muslims in general in the 1980s forced them to exile to Malaysia. Not only was they kept contact with their networks and devotees in Indonesia, they even broadened their networks internationally. It was in 1993 when they established an independence clandestine Islamic movement known later as the Jama'ah Islamiyah (JI). The broad networks of this underground organization are not only covered Southeast Asia, but also to Afghanistan. This organization was not well known yet until they return to Indonesia and discovered that it was the responsible for some devastating bombs in 2000 and also the Bali bombings in 2002 .

The dramatic political changes in Indonesia were partly responsible for the emergence and re-emergence of some radical Islamic groups. These groups emerged in many forms either formal organization such as the Majelis Mujahidin Indonesia (Council of Indonesian Mujahidin, $\mathrm{MMI}$ ), clandestine organizations such as the Jama'ah Islamiyah (JI), or in the form of vigilante forces (laskar) such as the Laskar Jihad and the Front Pembela Islam (Islamic Defender Front, FPI). This new era is also marked by the increasing demand of implementation of shari ${ }^{-6} a$ in many parts of Indonesia. Along with the emergence of the radical Islamic groups, the demand of the application of shari'ab laws emerges in some cities in Indonesia. In the context of Solo, the phenomenon of Pondok Ngruki (networks) re-emerged along with the JI. Although the demand of the application of shariab laws is not quite significant in Solo, some vigilante forces also emerged tremendously especially during the early years of post-Soeharto era which were more engaged on anti-immoral (ma siyab) activities. The Pondok Ngruki in its relation with the JI and the FPIS ${ }^{14}$ will represent the radical groups in this discussion.

${ }^{13}$ Usrah literally means nuclear family. This is such an organic term used by several Islamic movements to name their Islamic teachings' activities. Due to the stigma of Usrah, several Islamic movements employed the word halaqah (literally mean circle) at the end of 1980s, and finally they employ tarbiyab (literally mean education) since the end of 1990 s until recently.

14 Some other vigilante forces are Laskar Jundullah (the soldier of Allah), Laskar Hizbullah Sunan Bonang, Hawariyyun (the disciples), Brigade Hizbullah (the party of Allah Brigade), Barisan Bismillah (the Path of Bismillah), and Al-Ishlah (the reform). While some branch-level vigilante forces are the Gerakan Pemuda Ka'bah (the Ka'bah Youth Movement, GPK) and Front Pembela Islam (FPI, Islamic Defender Front). 
Some violent events during the post-Suharto era were allegedly committed by Ba'asyir (Pondok Ngruki). The involvement of some Ngruki graduates in the Bali bombings, and the revealed JI's responsibility for some devastated bombings convinced the authorities that Ba'asyir was the spiritual leader of the JI as the successor of Abdullah Sungkar. Finally, the authorities arrested him in October 2002 and began to bring him into trials. Undeniably, based on the all the above many people assumed that Pondok Ngruki is the centre for radical Islamism in sense of violence in Indonesia. Although some people are may objected to this accusation, the facts has proved on the other way around. In addition, the existence of several other Ngrukilike pesantrens co-founded by Ngruki graduates in the outer regions of Solo, as Dār al-Shahadah in Boyolali and Ma'had Aly Al-Nūr in Sukoharjo, convinced people to the accusation. Although the authorities could not prove the involvement of Ba'asyir in the JI, the existence of JI is undeniable. Moreover, that the region of Solo is quite central for JI underlined my suspicious that the region is prolific of such radical Islamism.

Similar to the Front Pembela Islam (FPI) of Habieb Rizieq in Jakarta, the existence of the Front Pemuda Islam Surakarta (FPIS) as a vigilante force is significant in Solo. ${ }^{15}$ As a local Islamic group, however, the FPIS is not only concerned with local issues in Solo but also in some national and international issues. Flock of people on the streets protesting some government's policies as well as US policies on Muslim world were among the activities of this organization. Similar to some other vigilante forces in Indonesia, the FPIS is concerned mostly with anti-ma'siyah (anti-immorality) actions. Although the FPIS knows exactly that Indonesia is not an Islamic state, this organization demand to reinforce the existing regulations concerning to moral issues. Therefore, the FPIS sweep some places such as prostitutions, gambling centres, cafes, and hotels which it regards as violating God's law. The most bizarre thing is its "sweeping" of foreigners especially Americans living in hotels in Solo. This action was conducted as its concern and sympathy to some Middle Eastern Muslim counties, especially to Iraq which was 'invaded' by the US. Interestingly, the FPIS is not a new

\footnotetext{
${ }^{15}$ Not to be misunderstood with the Front Pembela Islam (Islamic Defender Front, FPI) of Habieb Rizieq in Jakarta. The FPIS has nothing to do with the FPI, although the FPI has also its branch in Solo. Many times, some journalists wrongly wrote the FPIS as Front Pembela Islam Surakarta.
} 
phenomenon in Solo since it is only such a mean for another radical Islamic group well known as Jama'ah Gumuk. Finally, the existence of the FPIS among other vigilante forces and also Jama'ah Gumuk convinced me that Solo is prolific for radical Islamic groups. One significant feature of this radical Islamism is that most of its members are from lower level abangan communities at the periphery or suburb areas of Solo.

\section{Islamization and Abangan: the Fragmentation of Religious Authority}

The phenomenon of abangan as a majority in Solo marks the failure of Islamization in the region. Unlike other regions of Java in which Islamization was conducted by independent 'ulama's such as Wali Songo, the process of Islamization in Solo was monopolized by the Mataram kingdom which was known as the centre of Javanese culture. Not only was that Islam was featured by Javanese syncretism, but the Islamization itself only covered a small number of people. Inevitably, , polarization of Muslims in Solo is very significant beside the fact of the fragmentation of religious authority. This phenomenon could also be seen from the fact that no mainstreaming school of Islam in Solo such as the Muhammadiyah and Nahdlatul Ulama (NU). In the same way, some 'local' Islamic organization is mainstreaming in the region. Finally, the polarization of the Solonese and the fragmentation of religious authorities in Solo is featured by vast abangan community.

Since the mid of the $18^{\text {th }}$ century, Islam was a significant phenomenon in Surakarta kingdom. Historical account traces that Islam in Solo developed well since the reign of Susuhunan Pakubuwono II (1726-1749). The emergence of some royal poets such as Raden Ngabehi Ranggawarsita and their abundant works signed the dominant interpretation of Islam which was mixed with Javanese values, syncretism. The development of Islam in Solo was carried on by Susuhunan Pakubuwana IV (1788-1820) and Pakubuwana X (18931939). With their authorities, the pesantren of Jamsaren (1800s) and Madrasah Mamba' al-'Ulūm (1905) were established in Solo respectively. The control of the kingdoms and also the Dutch government, however, limited the independence of the institutions not only in interpreting Islam but also in disseminating it. Consequently, , Islam only spread on the higher level community and abangan Muslims is still majority in Solo. For this reason Ricklefs asserts that the 
strength of Javanism (Kejawen, Jw) is not a hindrance for Javanese to be a radical or fundamentalist Muslims. ${ }^{16}$

To discuss the development of Islam in Solo, it is worthwhile to describe some villages which were known as pious Muslim majority such as Kauman, Pasar Kliwon and Laweyan. The distinctiveness of these villages could be categorized as enclaves within the society. The division of communities to such enclaves was also intentionally designed for the role they have to carry out, such as Kauman for the aristocrats and Pasar Kliwon for Arabs. On the other hand, the arrangement was to distinguish their social statuses such as Kauman for santris (devout Muslims), and the rest regions are for abangan (nominal Muslims), including Pasar Kliwon and Laweyan. Although it seems that these three villages were well known as the centre of devout Muslims, history records that they did not have enough role in the process of Islamization in Solo. Although there were some devout Muslims, Haji Misbach as the propagator of Communism Islam prior to the independence of Indonesia is also from Kauman. In the same way, Laweyan was even the centre of red-Sarekat Islam (communism SI) although H. Samanhudi, the founder of the SI, is from this village. Finally, Arabs who resided at Pasar Kliwon also did not play any significant role in the development of Islam in the region. On this account, van den Berg states that only few colonies of Arabs were interested in Islamic preaching, but mostly in business. Moreover, he assert that most Arabs were reluctant to interact much with Javanese as they consider themselves had higher degree of social status. ${ }^{17}$ In the same way, indigenous ' 'ulama's did not like to cooperate with Arabs. All this means that the role of Arabs in developing Islam in Solo was insignificant. The fact that the majority of Javanese residing at Pasar Kliwon sub-district are abangan is another evidence.

Finally, the mass majority of abangan in Solo is also represented by the existence of Javanese mysticism (aliran kebatinan) in region. Not only is Solo the most widely spread of some Javanese mysticisms, it also the place of the establishment of several of them. Among various Javanese mysticisms, Sangkan Paran, Pangestu, Sumarah, Sapto

${ }^{16}$ For this issue see M.C. Rickelfs, "Islam and the Reign of Pakubuwono II, 17261749," in Peter G. Riddell and Tony Street, Islam: Essays on Scripture, Thought and Society: A Festschrift in Honour of Anthony H. Johns (Leiden: Brill, 1997), pp. 238-252.

${ }^{17}$ Further on this account, see L.W.C. van den Berg, Hadramaut dan Koloni Arab di Nusantara (Jakarta: INIS, 1989), pp. 103-104. 
Darmo, and Subud are widely accepted in Solo. The first two even founded in Solo, although in their later development they take other cities as their centres. Solo is among several important branch of Sangkan Paran, an oldest sect in Java. ${ }^{18}$ Although Sumarah is not centred in Solo, the region has an important role in this Javanese mysticisms. Due to the dynamic development of this sect in term of its 'worships', the Sumarah of Solo is becoming the gate for Westerners to follow this Javanese mysticisms. Hence, Paul Stange asserts that Sumarah has many things in common with Islam rather than their similarity on the meaning of their names. ${ }^{19}$ Further, he states that such Javanese mysticisms as Sumarah could also be seen as part of the process of Islamization. ${ }^{20}$ In my view, however, the abangan majority of the Solonese and the existence of some Javanese mysticism reflect the discontinued process of Islamization in Solo. Along with the limited range of Islamization, on the other hand, Christianization is also significant phenomenon since the Dutch colonialism.

In the early years of the New Order, the Christianization among the abangan majority had given to the rise of Islamic revivalism in Solo. The role of M. Natsir and Dewan Dakwah Islam Indonesia (Indonesian Islamic Propagation Council, DDII) was quite significant to the process of re-Islamization in the region. For this purpose, the DDII branch of Solo was founded along with the DDII of Central Java in Semarang. On a speech prior to the establishment of the DDII in Solo, Natsir strongly recommended the Solonese Muslims to establish more pesantrens and hospitals to counter the escalating efforts of Christianization in Solo. Eventually, the leader of the DDII of Solo, Abdullah Sungkar established a pesantren at the abangan majority community, Ngruki. Ahmad Khusnan, former leader of the DDII branch of Solo, acknowledges that Kustati and Yayasan Rumah Sakit Islam (Yarsis) Islamic hospitals were also established due to the financial assistance of the DDII as parts of the DDII's efforts to encounter Christianization in the region. In general, I tend to conclude that radical Islamism arising from Solo in the end of 1970s and early

18 Andrew Beatty, Varieties of Javanese Religion: An Anthropological Account (UK: Cambridge University Press, 1999), p. 188.

19 The term 'Sumarah' essentially means submission in Javanese what 'Islam' means in Arabic.

${ }^{20}$ Paul Stange, The Innner of Islamization of Java (Unpublished Ph.D Thesis at Murdoch University, 1980), p. 7. 
1980s was due partly to the escalation of Christianization in Solo, beside the fact that the pressure of the government.

As far as Islam in Solo is concerned, no single school of Islam is flourishing in Solo. Since the early of the 'age of motion', the abangan Solonese had been captured by the Sarekat Islam (SI). The 'tension' between Muhammadiyah and NU in Solo ended up with the Congress of Ulamā's at Pasar Kliwon in 1926. Ultimately, neither Muhammadiyah nor NU could be mainstream Islam in the region, even more at the ex-residency of Surakarta at large. The development of Islam in the region during the Old and New Order period was mostly influenced by 'local' schools of Islam. Since there is no single Islamic organization or 'Ulamā' having authority on Islam, Muslims in Solo are fragmented and diverge in many different schools of Islam. Finally, current development of Islam was fully characterized by local Islamic organizations which among them are radical.

\section{Social and Political Deprivation}

Along with the nominal characteristic of the Solonese, social and political deprivation played a significant role in the fragmentation of the society. In fact, the social deprivation is preceded by the ethnic problems in the city. The failure of indigenization of several other ethnics rather than Javanese in Solo brought about economic deprivation of the society. The fact that religious leaders do not play a significant role in Solo is also supported by the reality that neither traditional nor modern Solo municipality leaders do not pay their attentions to the society. History records that the patron-client system was not maintained well especially during the Dutch occupation. Finally, the political deprivation has given to the destruction of social system. The emergence of such radical Islamic groups as Sarekat Islam or Jama'ah Islamiyah is only a symptom of this fragmentation.

Solo is characterized by its plural society since the beginning of its existence. There are many ethnic populations living in Solo such as Javanese, Arabs, and Chinese. ${ }^{21}$ Like other plural cities in Indonesia, ethnicity has been becoming a sensitive issue. The difficulties and inability of ethnics especially Chinese to immerse to the Javanese society is one of the reason of the disparity between Chinese and

\footnotetext{
${ }^{21}$ In fact, there are many other ethnics in the city, i.e. Banjarese and Maduranese. However, since their numbers are not quite significant, their existence is not quite significant in Solo in many respects.
} 
Javanese. The diverse communities in Solo have been heightened by the diverse religions as a touchy entity. Conversely, Arabs who have the same religion and to some extend cultures could easily submerge with Java Solonese. The Arabs' acculturation was also supported by the fact that many Arabs married with Javanese women. ${ }^{22}$ In fact, this social situation is among the legacy of Dutch colonial government. Regardless of some complex and uneasiness of the Chinese in Indonesia during that period in general, ${ }^{23}$ the Chinese had such kind of privileges from the government. Their status as the second class, the same as Arabs, is completely different from the third class Javanese. The ability of Chinese to adapt to new social changes and play in it made them capable of surviving in new situation. ${ }^{24}$ All above privileges, social status, residential situation and opportunities or political access have led to such kind of social gap between Chinese in the one hand and Javanese on the other.

Since the beginning of the Solonese history, the lower level of abangan Javanese majority has been deprived socially as well as economically. The social stratification during the Dutch occupation had put the abangan Javanese into the lowest level after the Dutch and Javanese priyayi (high level class) at the top level, while Arabs and Chinese on the second level. ${ }^{25}$ This privilege of the Dutch gave also possibilities not only for Chinese to live at urban areas, but also other business conveniences. Eventually, the lower level of abangan Javanese were marginalized not only socially, but also economically. Such social and economic situation did not change significantly until recently.

\footnotetext{
22 According to van den Berg, only few Arab-born women stayed for long period in Indonesia. That is among the reason why most Arabs married with Indonesian women. Most Arabs in Indonesia the $20^{\text {th }}$ century were born in Indonesia. The existence of sayyid as the descendants of Prophet Muhammad is among the exception. See L.W.C. van den Berg, Hadramaut dan Koloni Arab di Nusantara. Jakarta: INIS, 1989 (the original book was in Dutch and published in 1887).

23 On this account, see Leo Suryadinata, Pribumi Indonesians, the Chinese Minority and China: A Study of Perceptions and Policies (Singapore: Marshall Cavendish Academic, 2005); Jemma Purdey, Anti-Chinese Violence in Indonesia, 1996-1999 (Leiden: KITLV, 2006).

${ }^{24}$ Further see M.C. Ricklefs, Yogyakarta di Bawah Sultan Mangkubumi 1749-1792: Sejarah Pembagian Jawa (Yogyakarta: Matabangsa, 2002).

25 On the account of Arabs in Java see Sumit K. Mandal, Finding Their Place: A History of Arabs in Java under Dutch Rule, 1800-1924 (Unpublished PhD thesis at Columbia University, 1994).
} 
Although many of the lower level Javanese today are living at the periphery of urban areas, they are constantly marginalized economically. Current success of Chinese in business is another social jealousy which adds another social gap with the lower level Javanese. In turn, recurring anti-Chinese riot has become long-lasting crucial issue in Solo. Interestingly enough, most riots caused by any social problems would finally lead to the destruction of Chinese properties. ${ }^{26}$

The absence of such social cohesion among the Solonese is also another major factor to the social fragmentation. The hegemonic power of the Solo kingdoms during the Dutch occupation is another deprivation of the abangan). The aristocrats of the Kasunanan and Mangkunegaran kingdoms have not been playing a significant role in the society. Since the very beginning of the history of Solo (Surakarta) in the $18^{\text {th }}$ century, politics was becoming a dominant issues among the aristocrats which finally split the Mataram kingdom into several kingdoms. The inability of the aristocrats to handle all social problems had drawn the involvement of Dutch business company (VOC) in both internally or externally social problems. The rise of the Sarekat Islam in the early $20^{\text {th }}$ century as the peak of social protest to the hegemony of the authoritarian Dutch government was not responded positively by the aristocrats. This ignorance was supported by the disharmonic relationship between the Kasunanan and Mangkunegaran kingdoms which is lasting until recently. The social gap between the aristocrats and kawula ${ }^{27}$ (lower class people) was not well mediated by the priyayi (upper class people). Upon the emergence of the Sarekat Islam, Kuntowijoyo asserts that it was as a result of collectively subconscious culture due to the failure of the priyayis mediate between raja and kawula. Until the independence of Indonesia in 1945, the kingdoms let alone Kasunanan reluctantly acknowledged the new state and still accepted the return of Dutch government in 1948. The detachment of the Kasunanan to the lower class people was responded by the reluctant of the people to the planning of Indonesian

${ }^{26}$ On this issue, see Jemma Purdey "The 'other' May riots: anti-Chinese violence in Solo, May 1998," in Charles A. Coppel, Violent conflicts in Indonesia: Analysis, Representation, Resolution (New York: Routledge, 2006).

${ }^{27}$ For the case of social class during that time, I tend to employ Kuntowijoyo's category: raja-priyayi-kawulo (king-upper class-lower class). Further on this account, see on his work, Raja, Priyayi \& Kawulo: Surakarta 1900-1915 (Yogyakarta: Penerbit Ombak, 2004), p. 9. 
government to give the Kasunanan a special autonomous region in 1946. The social actions in the name of anti-Swapraja (anti-autonomous government) were supported by majority of the Solonese. ${ }^{28}$ the failure of the kingdoms to be the pillar of such social cohesion for the society, to some extend, have split the unity of the society. This historical accounts show the seemingly less awareness of current authorities of the Solo municipality to this socio-cultural problems. These latent problems will continuously laying within this community unless there are such well-planned schemas to overcome the root of the problems properly.

Finally, the emergence of such radical Islamic groups could not be detached from the tension between the state and Muslims especially during the New Order. As argued by many, the Iranian revolution, the successful struggle against Soviet in Afghanistan, and the gains made by Islamic Brotherhood in Egypt have given to the rise of some Islamic revivalism in many Southeast Asian countries, including Indonesia. The emergence of such Islamic revivalism in Indonesia in the early of 1980s was responded negatively by the government. The government even considered Muslims as one of the obstacle of Indonesian development. This harsh relationship, finally, led to several conflicts between the state and Muslims in many different forms. Although this situation improved during the last ten years of the New Order regime, such situation to some extend has deprived Muslims.

\section{Globalized-Islam and Radical Islamism in Solo}

The phenomenon of radical Islamism in Solo would be best described as a resistant movement. In other words, the emergence of some radical Islamic groups could be seen as social movements which resist social changes that mostly do not accommodate their need. In some cases, social movements often serve to gradualize the process of social changes. In the case of Solo, however, some radical Islamic groups even want to alter the changes to support their necessities. The majority of lower level abangan society in Solo has been deprived not only in economics, but also social and political life. . Economic, social, and political developments in Solo in particular and in Indonesia in general do not accommodate their necessities, but even discontent them. In this respects, they see Islam as an alternative to solve their

\footnotetext{
28 Soedarmono and Muh. Amin, Solusi Konflik Pribumi dan non-Pribumi di Kota Solo (Laporan Penelitian Dosen Muda at UNS, 2002), p. 1.
} 
problems. Islamic teachings which they find not merely as religion but as a complete social system is the ultimate solution for all their problems. Therefore, it could be said that it is such an instant process of Islamization since they just 'leap' from abangan to Islam without undergoing necessary processes. Similar to what happened during the "age of motion", it may also possible that they do not really undergo such a process of Islamization; they just take a certain aspects of Islam (i.e., Sarekat Islam) to elevate them from their hopeless situation. Therefore, the involvement of such prominent Islamic organizations as Muhammadiyah and NU is very urgent to the Islamization process of the abangan society. Otherwise, such radical Islamic groups would consistently emerge from this society.

Globalization and modernization as the mainstream of the current world has drastically changed the world. Not only was globalization has shrunk the world, but it also brought about cultural fragmentation on regional levels. ${ }^{29}$ Further Tibi, who share views with Geertz on culture, looks at cultures as a framework for social production of meaning and then determine it on local situation. Accordingly, it was due to globalization that political Islam arises in most Muslim countries in the world. In the aftermath of the Iranian revolution in 1979, religious fanaticism and revivalism are arising in these countries, including Indonesia. The rapid mainstream of information and technology has marginalized the role of religion in the society. Conventional Islamic preaching, therefore, could no longer restrain the mainstream of modernization from the West. Inevitably, some communities felt that their culture and identities were in severe conditions; some of them may lose their social exchange, in economics for instance. The unavailability of a communication space for the community with the government has led them to such kind of social tension. In such plural society as Solo, a certain policy which does not accommodate to all parts of society will always be a seed of dispute.

In the perspective of some Islamic fundamentalism, modernization is viewed as an immense threat for Muslims since it is not only a concept but it is a social process which produces social products. One of significant consequent of modernity is the institutional differentiation of religious and secular spheres which was accompanied by the

${ }^{29}$ Basam Tibi, The Challenge of Fundamentalism: Political Islam and the New World Disorder (England: University of California Press, 2002), p. xvii. 
privatization of religion as well as its marginalization. ${ }^{30}$ Moaddel, however, tends to see the phenomenon of radical Islamic groups because of the ideological contentions in the Islamic world. ${ }^{31}$ For that reason, some 'ulama's frame globalization and modernization as a part of ghazw al-fiker. In addition, the hegemonic power of the West allows Westerners to introduce any regulations which would enable them to gain much benefit for themselves such as the invasion of Palestine and Iraq in the name of war on terrorism. In this point, Hart asserts that radical Islamism in Indonesia as well as in several other parts of Southeast Asia such as Malaysia, Thailand, and the Philippine are among the phenomena of Muslims' solidarity. ${ }^{32}$ Conclusively, the overwhelmingly emergence of Islamic political parties, radical Islamism groups, and vigilante forces in many parts of Indonesia are among the outcomes of globalization and modernization.

On the other hand, massive demographic changes as a result of modernization are also another factor to the rise of radical Islamism. Oliver Roy argues that Islamist movements in some secular nationalist government are among the result of unprecedented demographic change. ${ }^{33}$ Modernization in the form of economic development which is mostly take place in urban areas has attracted more rural families to come to the cities. The inability of the government to grasp all unemployment people has given to the rise of jobless at the periphery of the cities. Eventually, such this discontent society is easily mobilized by any social movements. In the context of Solo, this demographic shift has fuelled Islamism. Aside from the escalating social problems in this slum community, many of them are engaged with Islamic activities which to some extend offer them such instant remedy to their current problems. Undeniably, many activists of radical Islamism in Solo are from this lower level community.

\footnotetext{
${ }^{30}$ R. Scott Appleby, The Ambivalence of the Sacred: Religion, Violence, and Reconciliation (New York: Rowman \& Littlefield Publishers, 2000), p. 3.

${ }^{31}$ Mansour Muaddel and Kamran Talattof, "Contemporary debates in Islam: modernism vs fundamentalism: an anthology of Islamic thought," in Mansour Muaddel and Kamran Talattof (eds), Modernist and Fundamentalist Debates in Islam: a Reader (New York: Palgrave MacMillan, 2002), p. 3.

32 Natasha Hamilton-Hart, "Terrorism in Southeast Asia: Expert Analysis, Myopia and Fantasy" in The Pacific Review, vol. 18 No (3 September 2005): pp. 314-315.

${ }^{33}$ Further see, Olivier Roy, The Failure of Political Islam (Cambridge: Harvard University Press, 1996).
} 
Finally, the dramatic political shift to Reformation Era is the trigger of the emergence radical Islamism. Most social discontents which were forcefully suppressed by the New Order finally emerge following the decline of the regime. Social conflicts are becoming the most common phenomena of horizontal precariousness. Horizontal tensions in the forms of religious conflicts such as in Ambon and Poso are escalating during this period. The inability of the authorities to address the religious problems properly is such a 'political opportunity structure' which gave a chance for social actors to establish social movements. In the Solo context, this political opportunity has also given rise to the Islamic radical groups, or the resurgence of old radical Islamic groups. On the other hand, it was also due partly to the failure of the local government to grasp social figures and give them meaningful access to political institutions ${ }^{34}$ which led to the emergence of some radical Islamic groups. The re-emergence of Pondok Ngruki and jama'ah Gumuk in the form of the JI and FPIS respectively, and the establishment of some vigilante forces such as Laskar Jundullah and Laskar Hisbullah are among the result of this political conduciveness.

Some of the lower level abangan Solonese perceived the emergence of Islamic revivalism as an opportunity to resolve their social problems. Therefore, it could be clearly seen that most members of the above Islamic radical groups, including the vigilante forces, are mostly from abangan deprived-community at the periphery of Solo. Some Islamic terms have been used by these groups to attract more people to be involved in their own communities. Along with the convictions that Islam is the ultimate solution of the world disorder, shari ${ }^{-} a b$ and anti-West are among the most prolific issues to incite people to be involved in such radical Islamism groups. Nevertheless, different from some other radical Islamic groups such as in Banten, Garut, Tasikmalaya, and Bulukumba which fervently demand the implementtation of shari'ah as regional regulation (perda), the Islamic groups in Solo are not strong enough to demand such regulation. Although there are many abangan deprived-socially "converted" and involved in these religious radical groups, their number are not as significant compared to those who are not "provoked" and remains as ordinary abangan.

\footnotetext{
34 Mohammed M. Hafez, Why Muslims Rebel: Repression and Resistance in Islamic World (London: Lynne Rienner Publishers, 2003), p. xv.
} 


\section{Conclusion}

Solo is prolific for radical Islamic groups. The existence of the Pondok Ngruki, jama'ah Gumuk, and some Islamic vigilante forces in the city verify this assumption. The above phenomena also confirm that Pondok Ngruki and its related Islamic radical movements are not the single phenomenon of Islamic radicalism in Solo. However, it should be noted here that the Islamic vigilante groups hardly be categorized as radical since they concern more on moral issues and not on fundamental issues such as shari'ah or Islamic state. Moreover, these organizations do not have obvious views on Islamic values as other groups. However, I deliberately do not use rigid category in this case since there are many possibilities that these vigilante forces would turn into social movements due to favourable socio-political and cultural condition. Since in many cases these vigilante forces were involved in some radical violence, these groups could be categorized as radical in a broader term. Although some radical Islamic groups emerge in Solo, the demand for the implementation of shariah is not as in other regions such as Garut, Banten and Bulumkumba. In fact, the radical Islamism in Solo has not mainstreaming yet.

The phenomenon of radical Islamism in Solo is as a result of many socio-cultural and political factors. Social discontent economically and politically since the beginning of the $20^{\text {th }}$ century is among the most fundamental factors to the rise social deprivation. The lack of religious and traditional leaders in Solo society also led them to be such kind of loosely abangan society. It was globalization and political conduciveness which finally incite such moveable society into certain social movements. The involvement of some people in some radical Islamic groups is among their choice to resolve their socio-cultural problems they have undergone so far. In other words, radical Islamic activism is among some other social radicalism activisms which could happen in this society. In my view, the socio-cultural problems are still laying beneath the social structure of the Solonese which may explode if some political opportunities happened as the trigger to the emergence of a social movement. Compared to the mass support to the SI during the 'age of motion', to borrow Shiraishi's term, some present radical Islamic groups' offers to resolve some social problems are not touching the hearth of the loosely abangan society yet. In other words, although there are some radical Islamic groups in the region, these 
groups are not mainstreaming in Solo. This situation is due mostly to the success of some da'wah activities among these communities.

Finally, the role of some moderate Islamic organizations is very urgent to reduce such radical Islamism in Solo. In other words, they should intensify their dawah activities to touch the vast abangan majority in the region. Although such big Islamic organizations as Muhammadiyah and NU are not widely spread in Solo, it does not mean that the Solonese reject these organizations. Their previous failure of da'wah could lead them to change their methods of da wah. In addition, such coordinative agendas should be made between all moderate organizations to involve the society into their mainstream accordingly. As in other parts of Indonesia that NU is accepted well among the suburb areas, this organization could play in this level which is still abangan majority. Meanwhile, Muhammadiyah and also the Majelis Tafsir Alquran (MTA) which already has some networks among abangan in urban areas could broaden their networks within the areas. In addition, the role of some students' Islamic organizations such as the Kesatuan Aksi Mahasiswa Muslim Indonesia (Muslim Student Action Union, KAMMI), Ikatan Mahasiswa Muhammadiyah (Muhammadiyah Student Union, IMM), and Himpunan Mahasiswa Islam (Muslim Student Association, HMI) are absolutely needed to broaden their da wah activities not only among university students but also among the society, especially the abangan. The role of authorities to diverge all agendas of this huge process of santrinisasi (reIslamization) is also necessary, beside their main task to give some religious leaders in Solo some political access. Such comprehensive approach should be employed to reduce abangan majority and include them in the current mainstream of moderate Islam in Indonesia. []

\section{References}

\section{Books and Articles}

Appleby, R. Scott. The Ambivalence of the Sacred: Religion, Violence, and Reconsiliation. New York: Rowman \& Littlefield Publishers, 2000.

Azra, Azyumardi. "Globalization of Indonesian Muslim Discourse: Contemporary Religio-Intellectual Connections Between Indonesia and The Middle East." in Johan Meuleman. Islam in the Era of Globalization: Muslim attitude towards modernity and identity. London: RoutledgeCurzon, 2002. 
Beatty, Andrew. Varieties of Javanese Religion: An Anthropological Account. UK: Cambridge University Press, 1999.

Brenkman, John. Culture and Domination. Ithaca: Cornell University Press, 1987.

Coppel, Charles A. Violent conflicts in Indonesia: Analysis, Representation, Resolution. New York: Routledge, 2006.

Effendy, Bahtiar. Islam and the State in Indonesia. Singapore: ISEAS, 2003.

Hafez, Mohammed M. Why Muslims Rebel: Repression and Resistance in Islamic World. London: Lynne Rienner Publishers, 2003.

Hamilton-Hart, Natasha. "Terrorism in Southeast Asia: expert analysis, myopia and fantasy." in The Pacific Review, vol. 18 No. 3 September 2005.

Headly, Stephen C. Durga's Mosque: Cosmology, Conversion and Community in Central Javanese Islam. Singapore: ISEAS, 2004.

Kuntowijoyo. Raja, Priyayi \& Kawulo: Surakarta 1900-1915. Yogyakarta: Penerbit Ombak, 2004.

Mandal, Sumit K. Finding Their Place: A History of Arabs in Java under Dutch rule, 1800-1924. Unpublished Ph.D thesis at Columbia University, 1994.

Muaddel, Mansour and Kamran Talattof. "Contemporary Debates in Islam: Modernism vs Fundamentalism: an Anthology of Islamic Thought." in Mansour Muaddel and Kamran Talattof (eds). Modernist and Fundamentalist Debates in Islam: a Reader. New York: Palgrave MacMillan, 2002.

Pemberton, John. On the Subject of 'Java'. Ithaca \& London: Cornel University Press, 1994.

Pritchard, E.E. Evans. Social Anthropology. London: Cohen \& West Ltd, 1969.

Purdey, Jemma. Anti-Chinese Violence in Indonesia, 1996-1999. Leiden: KITLV, 2006.

Rickelfs, M.C. "Islam and the Reign of Pakubuwono II, 1726-1749." in Peter G. Riddell and Tony Street. Islam: Essays on Scripture, Thought and Society: A Festschrift in Honour of Anthony H. Johns. Leiden: Brill, 1997. 
Roy, Olivier. The Failure of Political Islam. Cambridge: Harvard University Press, 1996.

Sidel, John T. Riots, Pogroms, Jihad: Religious Violence in Indonesia. Ithaca and London: Cornell University Press, 2006.

Siraishi, Takashi. An Age in Motion: Popular Radicalism in Java 1912-1926. Ithaca, N.Y.: Cornell University Press, 1990.

Stange, Paul. The Innner of Islamization of Java. Unpublished PhD Thesis at Murdoch University, 1980.

Suryadinata, Leo. Pribumi Indonesians, the Chinese Minority and China: A Study of Perceptions and Policies. Singapore: Marshall Cavendish Academic, 2005.

Tibi, Basam. The Challenge of Fundamentalism: Political Islam and the New World Disorder. England: University of California Press, 2002.

van den Berg, L.W.C.. Hadramaut dan Koloni Arab di Nusantara. Jakarta: INIS, 1989. 